\title{
LEGAL ANALYSIS ON THE IMPLEMENTATION OF CORPORATE SOCIAL AND ENVIRONMENTAL RESPONSIBILITY BY REGIONAL GOVERNMENTS
}

\section{Roman Situngkir}

Regional Office of the Ministry of Law and Human Rights of North Sumatra

J1. Putri Hijau No. 4 Medan

roman.situngkir@yahoo.co.id

\section{ABSTRACT}

In Article 74 of Law Number 40 of 2007 concerning Limited Liability Companies, it is stated that, Companies that carry out their business activities in the field and / or related to natural resources are required to carry out social and environmental responsibility, these obligations are budgeted and calculated as the company's costs. Carried out with due regard to appropriateness and reasonableness and if the obligation is not carried out, then it will be subject to sanctions in accordance with the provisions of the prevailing laws and regulations. Referring to this provision, this authority is the authority of the central government. However, if we refer to Law Number 23 of 2014 concerning Regional Government, it also has authority in the social and environmental fields. So that in this paper we will examine the extent of regional authority in terms of corporate social and environmental responsibility in the regions. The research method used is normative juridical legal research. The results of the study show that the authority of local governments regarding corporate social and environmental responsibility is not clearly stated in Law Number 23 of 2014 concerning Regional Government. However, based on the principle of regional autonomy, local governments can exercise powers that are not absolutely the authority of the central government. Therefore, in the future, the regional government authority has a strong legal basis so that the authority regarding corporate social and environmental responsibility is contained in statutory regulations.

Keywords: Responsibility, Social, Company, Local Government.

Journal History

Received August 18, 2020;

Reviewed September 29, 2020;

Accepted Oktober 28, 2020;

Published : November 1, 2020

Copyright @2020 NLR. All right reserved. 


\section{INTRODUCTION}

Application of social and environmental Responsibility is a corporate responsibility towards stakeholders (stakeholders), and also its responsibility to shareholders ( shareholders ). In fact, until now, the definition of CSR is still diverse and has different definitions from one another. Globally, CSR is a company commitment to have a responsibility towards consumers, employees, shareholders, communities and the environment in all aspects of company operations. CSR is closely related to "sustainable development", where there is an argument that a company in carrying out its activities must base its decisions not only on financial factors, such as profits or dividends but also on social and environmental consequences for the present and for the long term.

In general, CSR is an improvement in the quality of life which means the ability of humans as individual members of society to be able to respond to existing social conditions, and to enjoy, utilize and maintain the environment or can be said to be an important process in regulating costs incurred and the benefits of business activities and stakeholders. both externally and internally.

The Indonesian economic system is based on kinship and is based on economic democracy, and the implementation of CSR arrangements is actually inseparable from the meaning of Pancasila itself, which is a philosophical foundation. In the constitution, this CSR principle is related to the aims and objectives of the nation and state as set out in the preamble to the 1945 Constitution which emphasizes that, "The Government of the State of Indonesia protects the entire Indonesian nation and all the blood of Indonesia and to advance public welfare, educate the nation's life, and participate in implementing world order based on freedom, eternal peace and social justice ". Apart from the preamble of the 1945 Constitution, it is also contained in Article 33 Paragraph (1) and (4), namely, Paragraph (1) states, "The economy is structured as a joint effort based on the principle of kinship", in Paragraph (4) it is stated, "The national economy is organized based on on economic democracy with the principles of togetherness, efficiency with justice, sustainability, environmental insight, independence, and by maintaining a balance between progress and national economic unity".

So far, the implementation of CSR regulations has been accompanied by other laws that are expected to support the implementation of CSR in Indonesia, such as the UUPLH, the Investment Law, the Manpower Law, and Government Regulations related to BUMN. With the existence of regulations that are more specific to discussing CSR, it must be accompanied by what sanctions will be applied in implementing CSR. If the laws other than the UUPT have regulated the sanctions but are still general in nature. 
Theoretically,

the responsibility of a legal entity (rechtsperson) can be divided into 2 (two) meanings, namely: 1) liability (juridical / legal responsibility),

and

2) responsibility (moral / ethical responsibility). ${ }^{1}$ According to Busyra Azheri, liability is a juridical responsibility,

while responsibility is a social or public responsibility. The principal difference between the two lies in the source of their arrangement. If a juridical liability is issued for the fault of one's own or someone else's actions, then it is a liability.

Local communities (in the regions) through the existence of corporate social obligations and the implementation of regional government affairs related to this matter greatly assist the government through social activities which are the responsibility of the company and the regional government itself, social assistance that is separate from the obligations of the state, to support the community which includes authority in carrying out different social responsibilities and jointly carrying out other obligations in terms of being ecologically responsible. The implementation of corporate social and corporate social obligations must be carried out jointly with partners who are taken after the candor and responsibility of parties authorized by law, the government as the controller

\footnotetext{
${ }^{1}$ Yosi Hadiyanto, Aspek Hukum AL-Wadi'ah Yad Adh-Dhamanah pada perbankan syariah, Article, Fakultas
}

must be able to bridge the interface and provide a sense of justice for the community in which the direction of implementing social obligations companies must be tailored to the capabilities of each company. However, if the error is not or has not been regulated juridically, then it is the responsibility of the responsibility. ${ }^{2}$ According to Pinto, liability refers to the result of failure to meet certain standards, while the form of responsibility is manifested in the form of compensation and restoration of damage or loss. ${ }^{3}$

Three parties have more specific interests, namely the government, local governments, the world of commerce such as private companies and government-owned companies and local governments and the closest community who are also partners. At that point, it is done separately by each company, because each company has natural characteristics and communities that are different from one another. Efforts to carry out corporate social obligations require cooperative energy from the government and society. The government as the controller is expected to play a role in creating and actualizing the implementation of corporate social duties within the country without burdening the company. The role of the community is also needed in the company's efforts to gain a sense of

\footnotetext{
Hukum Universitas Negeri Jember (2013).

${ }^{2}$ Ibid

${ }^{3}$ Ibid.
} 
security and familiarity in doing business.

Industrialization

and

speculation in different commercial forces regularly turn to methods of marginalization, deteriorating the environment, and not in accordance with the wishes of the surrounding community. Part of the company in ensuring the current environment. If technology transfer is associated with CSR, it must be considered so that the company actually carries out its obligations to protect the environment so that it does not interfere with the welfare of the community around the company. The centrality of the existence of law is very useful in economic activity so that it becomes stable and even develops. Meanwhile, responsibility is emphasized as obligation, judgment, ability and capacity. Obligations in terms of actions that should be taken, to repair or provide compensation for any damage that may be caused. ${ }^{4}$

The movement in the concept of corporate social responsibility from moving into a commitment to sharing benefits with the community, securing the environment, providing business, creating a small business and individual economy alike, engaging the community which includes Corporate Social and Environmental Responsibility. In any case, the main choice remains with the company to satisfy the various interests and needs of the community, which arise in the company's social and environmental obligations to make steps for the welfare of the people.

With the enactment of Law no. 40 of 2007 the meaning of responsibility (responsibility) in CSR turns into liability in TJSL. There is confusion of meaning between responsibility and liability $\mathrm{i}$ $\mathrm{n}$ TJSL. Responsibility voluntary as ethical responsibility, turned into a liability as a juridical responsibility (as a result of corporate activities that harm, such as pollution, destruction of the social order, and so on). This has resulted in a very broad coverage of TJSL, namely providing a legal basis for ethical and juridical responsibility. With TJSL, the company is both ethically and juridically responsible for all company activities, both detrimental and not.

Three parties with more specific interests, namely the government, local governments, the world of commerce such as private companies and government-owned companies and local governments and the closest community who are also partners. At that point, it was done separately by each company, because each company had natural characteristics and community conditions that were different from one another. Efforts to carry out corporate social obligations require cooperative energy from the government and society. The government as the controller is expected to play a role in creating and actualizing the implementation of corporate social duties within the

\section{${ }^{4}$ Ibid.}


country without burdening the company. The role of the community is also needed in the company's efforts to gain a sense of security and familiarity in doing business.

Industrialization

and

speculation in different commercial forces regularly turn to methods of marginalization, deteriorating the environment, and not in accordance with the wishes of the surrounding community. Part of the company in ensuring the current environment. If technology transfer is associated with CSR, it must be considered so that the company actually carries out its obligations to protect the environment so that it does not interfere with the welfare of the community around the company. The centrality of law existence is very useful in economic activity so that it becomes stable and even develops.

Law Number 23 of 2014 concerning Regional Government, in the consideration of letter $b$, states that the implementation of regional government is directed at accelerating the realization of community welfare through improving services, empowerment and community participation as well as increasing regional competitiveness by taking into account the principles of democracy, equity, justice and the uniqueness of a region in the system of the Unitary State of the Republic of Indonesia, based on this, the Regional Government must be able to explore the potential to increase regional development and improve the welfare of the community, related to regional development, it is expected to be able to boost the economy in various sectors including companies located in the region as a form investment to help local governments use the natural resources that exist in their respective regions.

In this regard, to carry out corporate social and environmental responsibility, the implementation of which must be based on the existing authority by the regional government, if you look at Law Number 23 of 2014 concerning Regional Government, as referred to in Article 12 paragraph (1) and paragraph (2), stated that Compulsory Government Affairs relating to Basic Services, include:

a. education;

b. health;

c. public works and spatial planning;

d. public housing and residential areas;

e. peace, public order and community protection; and

\section{f. social.}

Compulsory Government Affairs not related to basic services, including:

a. labor;

b. empowerment of women and child protection;

c. food;

d. land;

\section{e. living environment;}

f. population administration and civil registration;

g. community and village empowerment;

h. population control and family planning;

i. transportation;

j. communication and informatics; 
k. cooperatives, small and medium enterprises;

1. capital investment;

m. youth and sports;

n. statistics;

o. coding;

p. culture;

q. library; and

r. record management.

If you look at the regional government affairs in the social and environmental sector, which include matters related to basic services and those that are not related to basic services, of course this is the obligation of the regional government to implement them.

Related to this, the regulation regarding companies is regulated in Law Number 40 of 2007 concerning Limited Companies, this is not the authority of the Regional Government but the authority of the Central Government which is administratively carried out by the Ministry of Law and Human Rights of the Republic of Indonesia, hereinafter in Article 74 of the Law Number 40 of 2007 concerning Limited Liability Companies, states that, Companies that carry out their business activities in the field and / or related to natural resources are obliged to carry out social and environmental responsibility, these obligations are budgeted and calculated as company costs whose implementation is carried out with due regard for appropriateness and fairness. and if these obligations are not carried out, then they will be subject to sanctions in accordance with the provisions of the applicable laws and regulations, then this is further clarified in Article 2 of Government Regulation Number 47 of 2012 concerning Corporate Social and Environmental Responsibility, stated b that every company as a legal subject has social and environmental responsibility, and in Article 3 it is stated that social and environmental responsibility is an obligation for a company that carries out its business activities in the field and / or related to natural resources based on the law, then in article 4 that, Companies that carry out their business activities in the field and / or related to natural resources, in preparing and determining activity plans and budgets must pay attention to appropriateness and fairness and budget realization for the implementation of social and environmental responsibility carried out by the Company, is taken into account. as company costs. This PP is an implementation of law number 40 of 2007 concerning Limited Liability Companies.

In line with this, based on existing laws and regulations related to corporate social and environmental responsibility, it is not explicitly stated that the Regional Government has the authority to regulate or manage the implementation of the company's social and environmental responsibility, but on the other hand the Regional Government has business in the social and environmental field, of course its implementation must be based on the prevailing laws and regulations through regional regulations. 
Based on the background above, the problems are as follows:

1. How is the implementation of Corporate Social and Environmental Responsibility by the Local Government?

2. What is the legal basis for the Regional Government to regulate Corporate Social and Environmental Responsibility through

Regional

Regulations?

\section{METHOD}

Marzuki in Eka NAM Sihombing (2019) states that the normative juridical legal research method is a method that uses an approach that is based on the main legal material by examining theories, concepts of legal principles, norms, rules of legislation, court decision, agreement. The nature of the research used in this paper is prescriptive, adhering to the characteristics of legal science as an applied science, the prescriptions given in legal research activities must be able and possible to be applied. Therefore what is produced by legal research, even if it is not a new legal principle or a new theory, is at least a new argument. ${ }^{5}$

5 Eka N.A.M Sihombing, Eksistensi Paralegal dalam Pemberian Bantuan Hukum bagi Masyarakat Miskin (The Existence of Paralegals in Providing Legal Aid to the Poor), Jurnal Ilmiah Penegakan Hukum, Vol. 6, No. 1, June (2019).

6 Abdul Azis, Etika Bisnis Perspektif Islam: Implementasi Etika

\section{DISCUSSION}

\section{Definition of Corporate Social and Environmental Responsibility}

Social and environmental responsibility is a concept that organizations, especially companies, have a responsibility to consumers, employees, community shareholders and the environment in all operational aspects. ${ }^{6}$ In general, social and environmental responsibility is an obligation to take actions that protect and improve the welfare of society as a whole and the interests of the organization. $^{7}$ According to The World Business Council For Sustainable Development (WBCSD), it is stated that Corporate Social Responsibility is a business commitment to contribute to sustainable economic development, working with company employees, the families of these employees, as well as local communities and communities. as a whole in order to improve the quality of life. ${ }^{8}$

One form of socio-economic development has become a separate dynamic in the national development of the Indonesian nation because in practice there are still many challenges and demands that must be resolved. One of them is the implementation of the Social Security

Islami Untuk Dunia Usaha, (Bandung: Alfabeta, 2013), p. 208.

Sutamo, Serba-serbi Managemen Bisnis, (Yogyakarta: Graha Ilmu Yogyakarta, 2012), p. 21.

8 Bambang Rudito \& Melia Famiola, CSR (Corporate Social Responsibility) (Bandung: Rekayasa Sains, 2013), p. 106. 
System as mandated by the 1945 Constitution of the Republic of Indonesia. ${ }^{9}$

Corporate social and environmental responsibility can be defined simply as a concept that obliges companies to fulfill and pay attention to the interests of stakeholders in their profit-seeking operations. The stakeholders in question include share holders, employees (laborers), customers, local communities, government, nongovernmental organizations. ${ }^{10}$ In the development of business ethics to date, there is a more comprehensive idea regarding the scope of corporate social and environmental responsibility, namely: ${ }^{11}$

a. Company involvement in social activities that are useful for the benefit of the wider community. The company's involvement in social activities is intended to help promote and improve community welfare. These social activities are very diverse, for example donating funds to build houses of worship, building social infrastructure and facilities in the community (electricity, roads, water, recreation areas, etc.), conducting reforestation, protecting rivers from pollution or participating in cleaning rivers

${ }^{9}$ Pakpahan, Rudy Hendra., Eka N. A. M. Sihombing, Tanggung Jawab Negara Dalam Pelaksanaan Jaminan Sosial (Responsibility State In The Implementation Of Sosial Security), Jurnal Legislasi Indonesia, Vol. 9 No. 2 - Juli (2012). from pollution, conducting regular training It's free for young people who live around the company, giving scholarships to children from underprivileged families.

b. Economic Profits, according to Milton Friedman, the only social and environmental responsibility of a company is to bring maximum profit to the company, therefore the success of a company is economically and morally judged from the scope of social and environmental responsibility.

c. Fulfilling the legal rules that apply in a society, both those concerning the legal rules that apply in a society, both those concerning business interests and those concerning social life in general. As an integral part of society, companies have an obligation as well as an interest to maintain social order and order. Without this, the company's business activities will not run. One form of corporate social and environmental responsibility is complying with applicable laws.

d. Respect for the rights and interests of stakeholders or related parties who have direct or indirect interests in the business activities of a company.

210.

${ }^{10}$ Abdul Aziz, Op.Cit ., p. 209-

11 Suparnyo, Corporate Social Responsibility: Teori dan Praktik, (Semarang: Badan Penerbit Universitas Diponegoro), 2010, p. 173-174. 
Mandatory government affairs related to basic services in Law Number 23 of 2014 concerning Regional Government (UU Pemda) are also related to the obligation to serve social matters (Article 12 paragraph (1) letter f) and the obligation to provide basic services to the environment (Article 12 paragraph (2) letter e of the Regional Government Law).

The definition of social responsibility in several laws turns out to be not only the responsibility of the company and the central government, but local governments also have social and environmental responsibility when referring to Article 12 paragraph (1) letter $\mathrm{f}$ and 12 paragraph (2) letter e of the Regional Government Law .

CSR in a broad sense is considered a more humane concept in which organizations are seen as people who distribute something ethically. ${ }^{12}$ Business organizations can choose which activities or behaviors are the most important morals in certain circumstances by applying ethical standards. For example the adoption of a "brilliant run the show" guideline that instructs individuals or parties to treat others the same way they need to be treated. This concept also accepts that

12 Fajar Nussahid, Praktik Kedermawanan Sosial BUMN Analisis terhadap Model Kedermawanan PT Krakatau Stei, PT Pertaminan, PT Terkomunikasi Indonesia, Jurnal the right activities undertaken by companies based on ethical standards alone will provide the most prominent benefits to society. ${ }^{13}$

The distinctive feature of corporate social responsibility is related to part of the responsibility for coordinating government assistance through different social activities to support the community related to corporate training, supporting various social teachings as well as offering assistance with other obligations in understanding matters relating to community needs, including making differences address environmental problems.

\section{Benefits of Corporate Social and Environmental Responsibility}

The clear benefit for the company of providing corporate social and environmental responsibility is the emergence of a positive image from the community regarding the company's presence in its environment. The company's activities in the long term will be considered a positive contribution to society. Apart from helping the community's economy, the company is also considered to be with the community to help create a better

Galang, Vol. 1, No 2, Januari (2006), p. 5.

${ }^{13}$ Jones Great R,

Oraganizational Theory, (New Jersey:

USA Prentice-Hall Inc, 2001), p. 15. 
situation in the future. Some of the TJSL, namely: ${ }^{14}$

a. Benefits for society

The benefits for society from social and environmental responsibility carried out by the company are very clear, in addition to the fact that several community interests are considered by the company, the community will also get a new view of the company's relationship with the community which so far has only been understood as the relationship between producers and consumers or the relationship between sellers and buyers only.

b. Benefits for the government

The benefits of being a government with the existence of corporate social and environmental responsibility from the government are very clear. In the end, the government does not only function as a referee who determines the rules of the game in public relations with the business world and imposes sanctions on those who violate them. The government as the legitimate party to change the society order for the better will get a partner in realizing the community order. Part of the government's tasks can be carried out by members of the public, in this case companies or business organizations. ${ }^{15}$

c. The benefits of a business that adopts a social and environmental responsibility program include increased reputation, increased shareholder value, motivated and happy employees.

\section{${ }^{14}$ Budi Untung, CSR Dalam}

Dunia Bisnis, (Yogyakarta: ANDI, 2014), p. 12. d. Corporate Social and Environmental Responsibility in Law

Corporate social and environmental responsibility is a matter that is only regulated in the provisions of this Limited Liability Company Law. The intended background of this provision is as a form of corporate social responsibility towards the environment and the condition of the community around the company's place of business. This provision is not comprehensive in nature, but has certain limitations and conditions whose implementing regulations will be further regulated by government regulations. This provision also aims to continue to create corporate relations that are harmonious, balanced and in accordance with the environment, values, norms and culture of the local community.

Concept of Corporate Social and Environmental Responsibility in Indonesia

Social and environmental responsibility (TJSL) Companies in modern history have been known since Howard R. Bowen published a book entitled Social Responsibilities of The Businessman in the 1950-1960 era in the United States. The public's recognition of the principles of social responsibility that he put forward resulted in him being crowned by

${ }^{15}$ Ernie Tisnawati Sule, Kurniawan Saefullah, Pengantar Manajemen, (Jakarta: Kencana, 2010), p. 81-82. 
acclamation as the father of CSR. Even in the 1960s, Bowen's thought was continuously developed by various other business sociologists such as Keith Davis who introduced the concept of Iron Laws of Responsibility. ${ }^{16}$

The definition of TJSL according to Edi Suharto, is "the concern of a company that sets aside part of its profit for the benefit of human development (people) and the environment (planet) in a sustainable manner based on accurate and professional procedures". ${ }^{17}$

TJSL according to Ismail Solihin definition, is "one of the forms of its responsibility to stakeholders

(stakeholders) ${ }^{18}$ _Suhandari M. Putri stated regarding TJSL is "The commitment of the company or the business world to contribute to sustainable economic development by paying attention to corporate social responsibility and emphasizing the balance between attention to economic, social and environmental aspects". ${ }^{19}$

On the basis of concerns from the community around these SDA companies that prompted the government to dispute the rules related to TJSL in Law Number 40 of

\footnotetext{
${ }^{16}$ Hendrik Budi Untung, Op. Cit., p. 37.

${ }^{17}$ Edi Suharto, Pekerjaan Sosial di Dunia Industri, Memperkuat CSR, (Bandung: CV. Alfabeta, 2009), p. 105.

18 Ismail Solihin, Corporate Social Responsibility From Charity to
}

2007 concerning Limited Liability Companies. So with that stakeholder theory which means that the company will disclose corporate social responsibility to stakeholders, especially the surrounding community so that the company is able to survive in its business. At this time, mining exploration company business activities are required to do more than just generate company profits or profits. As a form of social responsibility, mining exploration companies must provide benefits to the communities in the company environment.

The basic concept of CSR is strengthening related to environmental problems and also focuses on reducing poverty. In the expansion to community and corporate empowerment, it is clear that operations will run easily. If the relationship between the company and the community does not show it can be confirmed that there is a problem. The implementation of the CSR program is fully recognized by the company. It was taken into account by the company's need for consideration for the use of CSR funds. ${ }^{20}$

The facts show that many companies only carry out operational activities but pay very little attention

Sustainability, (Jakarta: PT. Riau Andalan Pulp and Paper, 2008), p. 2.

${ }^{19}$ Suhandari M. Putri., Op. Cit.,

p. 1 .

20 Hendrik Budi Untung, Corporate Social Responsibility (CSR), (Jakarta: Sinar Grafika, 2008), p. 3. 
to the social and economic interests of the surrounding communities.

In implementing CSR, there are at least four CSR models or patterns that are generally applied by companies in Indonesia, namely

a. Direct involvement. The company runs its CSR program directly by organizing its own social activities or making donations to the community without intermediaries. To carry out this task, a company usually assigns one of its senior officers, such as the corporate secretary or public affairs manager, or becomes part of the duties of the public relations officer .

b. Through foundations or corporate social organizations. The company establishes its own foundation under the company or group. This model is an adoption of a model commonly applied in companies in developed countries. Usually, companies provide start-up funds, regular funds or endowments which can be used regularly for foundation activities.

c. Partnering with other parties. Companies organize CSR in collaboration with social organizations / non-governmental organizations (NGOs / NGOs), government agencies, universities or mass media, both in managing funds and in carrying out their social activities.

d. Support or join a consortium. The company co-founded, became a

${ }^{21}$ Saidi Zaim dan Hamid Abidin., Menjadi Bangsa Pemurah: Wacana dan Praktek Kedermawanan Sosial di member or supported a social institution established for certain social purposes. Compared to other models, this pattern is more oriented towards providing corporate grants that are "development grants" in nature. The consortium or such institutions trusted by the companies that support them are pro-active in seeking cooperation partners from the operational institutions and then develop mutually agreed programs. ${ }^{21}$

If we analyze the CSR models in Indonesia, we can use mixed model, it's depend on the deal. TJSL has become an inevitable demand along with the emergence of community demands against the company. The company realizes that success is aware that its success in achieving its goals is not only influenced by internal factors but also by the factors of the community around it. This means that there has been a shift between the company and the community. The company, which previously positioned itself as a donor through charity and philanthropic act ivities, is now positioning the community as a partner that contributes to the sustainability of a company. The definition of TJSL itself is so diverse, depending on the company's vision and mission that is tailored to the needs, goals, desires and interests of the community. The definition of TJSL has been proposed by several experts, including the

Indonesia, (Jakarta: Piramida, 2004), p. 32. 
definition put forward by Maignan \& Ferrel which defines TJSL as. $A$ business acts in socially responsible manner when its desicion and action account for and balance diversestakeholder interest. ${ }^{22}$ This definition emphasizes the need to pay balanced attention to the interests of various stakeholders in every decision and action taken by business people through socially responsible behavior. Meanwhile, the European Commission provides a definition in practical terms, is how companies voluntarily contribute to the formation of a better society and a cleaner environment. ${ }^{23}$

The basic principles of social responsibility which form the basis for implementation that animate or inform in decision-making and social responsibility activities according to ISO 26000 include:

1. Compliance with law

2. Respect for international instruments / bodies

3. Respect for stakeholders and their interests

4. Accountability

5. Transparency

6. Ethical behavior

7. Take precautions

8. Respect the fundamentals of human rights.

Article 74 of Law number 40 of 2007 regarding Limited Liability Companies has basically ended the debate about whether or not CSR or Social and Environmental Responsibility (TJSL) is compulsory for limited liability companies. This Law imperatively explains that CSR is a legal obligation for companies that meet the criteria stipulated by the law. The TJSL regulated in the 2007 UUPT was inspired by the recent view that taught the company as a company that carries out activities in the midst of community life, the company must take responsibility for the social problems faced by the local community.

In Indonesia, the etymological definition of CSR is often translated as corporate social and environmental responsibility. However, after 16 August 2007, CSR in Indonesia has been regulated in Law Number 40 of 2007 concerning Limited Liability Companies which replaces Law Number 1 of 1995 concerning Limited Liability Companies. CSR which is known in this Law as contained in Article 74 paragraph (1), (2), (3) and paragraph (4) which reads:

(1) Companies that carry out their business activities in fields and / or related to natural resources are obliged to carry out Social and Environmental Responsibility.

(2) Social and Environmental Responsibility as referred to in paragraph (1) is a company obligation that is budgeted and calculated as company costs, the implementation of which is carried out with due regard to appropriateness and fairness.

(3) Companies that do not carry out the obligations referred to in paragraph (1) will be subject to

${ }^{23}$ Ibid., p. 11. 
sanctions in accordance with the provisions of laws and regulations.

(4) Further provisions regarding Social and Environmental Responsibility shall be regulated in a Government Regulation.

The company must have goals and objectives as well as business activities that do not conflict with statutory provisions, public order, and / or morality, because the provisions governing PT are too brief, Article 1 confirms the enactment of the Civil Code in the field of commercial law. .

Article 74 paragraph (1) basically states that every company that trades within the territory and / or which is related to normal assets is required to carry out social and environmental obligations. In line with the provisions in Article 74, the clarification of the article provides a limitation that the company conducting its trade is a company whose trading controls and uses normal assets. Whereas companies that carry out their trading activities related to shared resources are companies that do not supervise and do not use characteristic assets, but their trading practice has an influence on the work of general asset capabilities.

Sanctions that can be empowered are also regulated in Article 7 and Article 5 point (2) of Government Regulation Number 47 of 2012 concerning Social and
Environmental Responsibility of Limited Liability Companies, which in essence stipulates that the costs of social and environmental responsibility are carried out at the company's expense. Carrying out the social and environmental obligations of the company, limited risk is subject to sanctions in the agreement with the entry into force.

Article 1 of the KUHD reads: "The Civil Code also applies to matters that are regulated by this law, only in this legal book it is not specifically regulated to deviate."

Taking into account the provisions of Article 1 of the KUHD, the KUHD itself is a lex specialis ( special law) dealing with the Civil Code. If that is the case, the company regulation in the KUHD is a lex specialis or corporate forms of a partnership ( maatschap,

partnership ) or association that are regulated in the Civil Code as well as those regulated in other laws and regulations. So the company law regulated in the KUHD, is a special civil provision that regulates the law of an engagement or agreement between parties that arise specifically from the field of Limited Liability Companies, while the engagement law regulated in Book Three of the Civil Code is a rule of legal relations between one individual and others in all fields of business according to their own will and needs. ${ }^{24}$
${ }^{24}$ M. Yahya Harahap, Hukum

Perseroan Terbatas, (Jakarta, Sinar

Grafika, 2009), p. 22. 


\section{Legal Basis for Implementation of Corporate Social and Environmental Responsibility by Local Governments through Regional Regulations}

Economic development and growth in the context of national development in a country is not the responsibility of the government alone. Every citizen or company must have responsibility for economic development and growth in the framework of national development. One of the factors that promote economic growth in the context of economic development is the business world, namely the results of the implementation of various agencies and parties. These agencies and parties include companies. So, the company as one of the economic actors must still run its business and earn profits and must also pay attention to the environment and the surrounding community.

The following are
regulations regarding CSR in
Indonesia:

Law Number 40 of 2007 concerning Limited Liability Companies "Social and Environmental Responsibility is the company's commitment to participate in sustainable economic development in order to improve the quality of life and the environment that is beneficial, both for the company itself, the local community, and society in general. " Article 74, which reads:

(1) Companies that carry out their business activities in fields and / or related to natural resources are obliged to carry out Social and Environmental

Responsibility.

(2) Social and Environmental Responsibility as referred to in paragraph (1) is a company obligation which is budgeted and calculated as corporate costs, the implementation of which is carried out with due observance of appropriateness and fairness.

(3) Companies that do not carry out the obligations referred to in paragraph (1) shall be subject to sanctions in accordance with the provisions of laws and regulations.

(4) Further provisions regarding Social and Environmental Responsibility shall be regulated in a Government Regulation.

In Article 74, there are lots of debates that occur especially among entrepreneurs, some people and entrepreneurs feel that the application of Article 74 creates discrimination because it only requires CSR to companies that carry out business activities in the field and / or related to natural resources, which is a question. What about companies that do not carry out business activities in the field and / or related to natural resources, are they not obliged to implement CSR? This was answered explicitly by the Constitutional Court decision by considering several things, one of which was that the damage to natural resources and the environment in Indonesia had reached a very alarming level, both for present and future generations. Therefore, the role of the state by controlling the earth, water, air and natural resources 
contained therein, including to regulate, cultivate, maintain and supervise, is intended to build a good and sustainable development which is aimed at all stakeholders (stakeholders) which should not be ignored. ${ }^{25}$

For this reason, it is necessary to have an explanation regarding the contents of Article 74 of the Company Law, where the legal empirical aspects can be seen one by one. The formulation of Article 74 of the Company Law can be described as follows:

a. In paragraph (1), it is stated that the obligation to implement CSR for companies that carry out business activities in the field and / or related to natural resources is only looking at the core business side of the company. Even though the company does not carry out direct exploitation, as long as its business activities have an impact on the function of natural resource capabilities, the company is obliged to carry out CSR. Thus it is clear that the concept of CSR which was originally only a moral obligation, then with the enactment of the Company Law, it will turn into a legally accountable obligation. This is done by considering all the potential that exists in the company's environment.

b. Paragraph (2) states that the cost of implementing CSR is calculated as

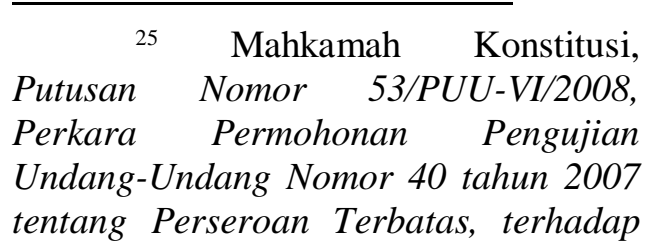

a component of the company's costs. The costs incurred to implement this CSR should be taken into account at the end of the financial year as one of the company expenses. In this case, so that it can be used as a tax reduction cost, the CSR and environmental activity plans to be implemented and the required budget must be included or included in the annual work plan. Regarding the budget for implementing CSR, it is carried out in a proper and reasonable manner, namely with the understanding that the costs must be adjusted according to the intended benefits from implementing CSR itself based on the company's financial capacity.

c. In paragraph (3) it is stated that the sanctions imposed on companies that violate the provisions regarding social and environmental responsibility are sanctions stipulated in the relevant laws and regulations. This means that the sanctions given are not sanctions for not carrying out CSR according to the Company Law, but because the company ignores CSR so that the company violates applicable social and environmental regulations.

d. In paragraph (4) it is stated that the regulations that cover CSR regulations in Indonesia, the government needs to make implementing regulations in the form of this Government

UUD 1945. Tanggal 15 April 2009.” Pendapat Mahkamah tentang Pertimbangan konstitusionalitas norma pengujian Pasal 74 UUPT", p. 90. 
Regulation. It is hoped that the government will not misinterpret CSR so that the rules that are made will be burdensome for the company and will eliminate arrti from the CSR itself. With the inclusion of CSR, which initially emerged because of the company's awareness and was more of a moral liability to become legal liability, even though the sanctions that the company received were from the related laws. ${ }^{26}$

Therefore, the nature of CSR in Indonesia, which was initially voluntary, is mandatory for companies to carry out CSR programs. And there is no reason for companies not to implement CSR principles in their business activities. So that in order for this obligation to be imperative, it must be accompanied by regulations so that Law Number 40 of 2007 concerning Limited Liability Companies appears which includes a CSR clause in Article 74 of the Company Law.

Basically, the formation of regulations related to TJSL is also inseparable from the existence of stakeholder theory and theory of legitimacy. In this case, the existence of the TJSL regulation in Article 74 of Law Number 40 of 2007 concerning Limited Liability Companies, cannot be separated from the role of the government in trying to consider the conditions of stakeholders around large companies in Indonesia. Apart from that, it is not surprising that at this time the community is anxious, even afraid of the direct impact and implications of the activities of companies exploring natural resources. The activities of these SDA companies sometimes cause bad psychological effects for the community. It can also have various logical consequences for the surrounding community. Among them are changes in the structure and socio-economic and cultural structure of the community, physical conditions and environmental damage, as well as the psychological burden and trauma of the surrounding community. Local regulation and CSR must to relating each other. So that, it will be effective.

\section{Government Regulation Number 47 of 2012 concerning Corporate Social and Environmental Responsibility}

Government Regulation Number 47 of 20112 concerning Social and Environmental Responsibility of Limited Liability Companies is the implementing regulation of Article 4 of Law Number 40 of 200 concerning Limited Liability Companies. Article 2 states "Every company as a legal subject has social and environmental responsibility". This means that every company that is legally incorporated by law has social and environmental responsibilities.

Article 3 states "The social and environmental responsibility as referred to in Article 2 shall become

${ }^{26}$ Hendrik Budi Untung, $O p$.

Cit., p. 93-100. 
the obligation of the Company which carries out its business activities in the sector and / or related to natural resources based on the Law".

\section{Law Number 19 Year 2003 regarding State-Owned Enterprises \\ To overcome the weak} management of BUMN, the government has issued Law No. 19 of 2003 on State-Owned Enterprises, which tries to adopt some good corporate governance principles. This is clearly stated in Article 5 paragraph (3) jo. Article 6 paragraph (3) of the BUMN Law: "In carrying out their duties, the Board of Directors, commissioners and supervisors must carry out the principles of professionalism, efficiency, transparency, independence, accountability, responsibility and fairness".

Article 87 paragraph (2) of the BUMN Law stipulates that "BUMN employees can form labor unions in accordance with the provisions of laws and regulations". Article 88 paragraph (1) of the BUMN Law stipulates that "BUMN can set aside a portion of their net profit for the purposes of fostering small businesses / cooperatives as well as fostering communities around BUMN". Article 90 of the BUMN Law stipulates that "BUMN within the limits of propriety can only make donations for charity or social purposes in accordance with the provisions of laws and regulations".

Law Number 19 of 2003 concerning State-Owned Enterprises also regulates several things that can be related to CSR, namely in Article 2 Paragraph (1), where it is determined that, the aims and objectives of establishing BUMN are:

a. Contribute to the development of the national economy in general and state revenues in particular;

b. Chasing profit;

c. Carrying out public benefits in the form of the provision of goods and / or services of high quality and adequate for the fulfillment of the lives of many people;

d. Become a pioneer of business activities that cannot be implemented by the private sector and cooperatives;

e. Actively participate in providing guidance and assistance to economically weak entrepreneurs, cooperatives, and the community.

Article 66 Paragraph (1) also concerns matters relating to CSR where the government can assign a special assignment to BUMN to carry out public benefit functions while still paying attention to the goals and objectives of BUMN activities. In the Regulation of the State Minister for BUMN Number: Per-05 / MBU / 2007 dated 27 April 2007, it is known as the Community Development Program, hereinafter referred to as the BL Program, which is a program to empower the social conditions of the community by BUMN through the use of funds from the BUMN's profit share. 


\section{Law Number 25 of 2007 concerning Investment}

In Law Number 25 of 2007 concerning Investment (the Investment Law) which regulates CSR, Article 15 reads that every investor is obliged to:

a. Applying the principles of good corporate governance;

b. Carry out corporate social responsibility;

c. Making reports on investment activities and submitting it to the Investment Coordinating Board;

d. Respect the cultural traditions of the community around the location of investment business activities; and

e. Comply with all provisions of laws and regulations.

\section{Law Number 32 Year 2009} concerning Environmental Protection and Management

The realization of the fulfillment of the right to the environment is the emergence of Law Number 4 of 1982 concerning Basic Provisions for Environmental Management which has been amended by Law Number 23 of 1997 concerning Environmental Management and then amended again to Number 32 of 2009 concerning Protection and Management of the environment. If UPPLH is linked to CSR, the company must fulfill the right to the environment. This is in accordance with the articles concerning CSR in UPPLH, namely
Article 5 paragraph (1) Everyone has the same rights to a good and healthy environment. Furthermore, Article 6 paragraph (2) Every person conducting a business and / or activity is obliged to provide true and accurate information regarding environmental management.

Article 14 paragraph (1) To
ensure the preservation of
environmental functions, every business and / or activity is prohibited from violating the quality standards and standard criteria for environmental damage. Article 15 paragraph (1) Every business plan and / or activity which is likely to have a large and important impact on the environment is obliged to have an analysis of environmental impacts.

Article 16 paragraph (1) Every person in charge of a business and / or activity is obliged to manage waste resulting from his business and / or activity. 16 paragraph (2) The party responsible for the business and / or activity as referred to in paragraph (1) may hand over said waste management to another party. Article 17 paragraph (1) Every person in charge of a business and / or activity is obliged to manage hazardous and toxic materials. Article 17 paragraph (2) Management of hazardous and toxic materials includes: producing, transporting, distributing, storing, using and / or disposing.

Article 18 paragraph (1) Every business and / or activity that creates a large and important impact on the environment is required to have an analysis of environmental impacts in order to obtain a license to conduct 
business and / or activity. Article 19 paragraph (1) In issuing a license to conduct a business and / or activity, the following must be considered:

a. spatial plan;

b. public opinion;

c. considerations

and

recommendations of the competent authority related to the said business and / or activity.

With the various laws and regulations that have been described above related to corporate social and environmental responsibility, there is no single mention that the Regional Government is given the authority to regulate corporate social and environmental responsibility, although this does not mean that the Regional Government does not have a role and responsibility. According to the author's understanding that Regional Government has a very strategic role in carrying out corporate social and environmental responsibility in relation to Regional Autonomy, that the principle of regional autonomy is directed to be able to explore the potential that exists in each region in order to achieve prosperity and improve the community's economy, then every company located in an area that utilizes natural resources is obliged to contribute to development in accordance with the prevailing laws and regulations.

CSR in a broad sense is considered a more humane concept in which the organization is seen as an ethical operator. Therefore, with or without enforcement of the law, companies must maintain in-depth quality. Considering that it is true that despite the fact that there is no legal or moral rule governing society, the social obligation can be carried out under various circumstances with respect to which the best arises or is slightly uncomfortable for its partners.

The existence of companies operating in the regions certainly has a very good impact on all parties which will become the needs of everyone, including employment and will reduce unemployment, to accommodate regional interests as mandated in the 1945 Constitution of the Republic of Indonesia. Article 18 paragraph (2) and paragraph (5) states that the Regional Government has the authority to regulate and manage government affairs by itself according to the principles of autonomy and assistance tasks and is granted the widest possible autonomy. The provision of the widest possible autonomy to the regions is directed at accelerating the realization of community welfare through improved services, empowerment and community participation. In order to provide wider space for the Regions to regulate and manage the lives of their citizens, the central government in forming policies must pay attention to local wisdom and vice versa when forming regional policies in the form of Regional Regulations and other policies it should also pay attention to national interests. A region as a legal community unit that has autonomy has the authority to regulate and administer its region according to the 
aspirations and interests of its people as long as it does not conflict with the national legal order and public interest.

In the context of regional autonomy, of course the Regional Government is given the authority to form regional regulations, as mandated in Article 18 paragraph (6) of the 1945 Constitution of the Republic of Indonesia, states that, the Regional Government has the right to stipulate regional regulations and other regulations to implement autonomy and Assistance tasks, in line with Law Number 23 of 2014 concerning Regional Government, in Article 236 paragraph (1) To carry out regional autonomy and assistance tasks, regions form Regional Regulations and paragraph (2) Regional Regulations are formed by DPRD with the joint approval of the Regional Head . On this basis, the Regional Government is given the authority to formulate Regional Regulations, related to the subject matter in writing this paper is the implementation of Corporate Social and Environmental Responsibility by Local Governments through Perda.

With the explanation above related to the authority of Regional Government which becomes governmental affairs in the social and environmental fields, this is an obligatory affair related to basic services and mandatory affairs that are not related to basic services as referred to in article 12 paragraph (1) letter f and paragraph (2) letter e, then to exercise this authority the Regional Government must regulate by forming a Regional Regulation on Corporate Social and Environmental Responsibility with due observance of existing laws and regulations and may not conflict with higher laws and public interests as well as remain within the corridors of the national legal system.

As for several regions, both provincial and district / city, which stipulate Regional Regulations on Corporate Social and Environmental Responsibility, including:

1. Regional Regulation of the City of Tasikmalaya Number 4 of 2015 concerning Guidelines for the Management of Corporate Social and Environmental Responsibility Programs and Partnership and Community Development Programs in Tasikmalaya City.

2. Jepara Regency Regional Regulation Number 3 of 2014 concerning Corporate Social Responsibility.

3. Regional Regulation of Sukoharjo Regency Number 15 of 2016 concerning Corporate Social and Environmental Responsibility.

4. Central Java Provincial Regulation Number 2 of 2017 concerning Corporate Social and Environmental Responsibility.

\section{CONCLUSION}

Local government in carrying out corporate social and environmental responsibility has a very broad role in the framework of 
development in various fields and companies are required to contribute according to the appropriateness and fairness of the company. In its implementation, the Regional Government must be guided by the prevailing laws and regulations in accordance with the authorities which are government affairs based on Law Number 23 of 2014 concerning Regional Government, although the Law is not clearly stated, it does not reduce the existing authority and the principle of regional autonomy is that a region is given a freedom to administer and regulate various government laws covering authority in all areas of government, except in other areas which have been determined to be the authority of the Central Government.

To implement regional autonomy, a legal umbrella is required through regional regulations as a guideline or legal basis for local governments to manage or regulate corporate social and environmental responsibility, so that there is synchronization or harmonization between companies and local governments towards better regional development. through programs established by the Regional Government and the company every year by taking into account the needs of the community in order to improve the quality of life of the community. for the sake of achieving community welfare.

One of the content of regional regulations is the assistance task given by the Central Government to the Regional Government, related to the assistance task, it should be regulated in laws and regulations regarding corporate social and environmental responsibility so that local governments have a strong legal basis when forming regional regulations. regarding corporate social and environmental responsibility, so that local governments can further optimize their duties, functions and authorities in accordance with applicable laws and regulations in order to achieve community welfare and improve the community's economy.

\section{REFERENCES}

Azis, Abdul. Etika Bisnis Perspektif Islam: Implementasi Etika Islami Untuk Dunia Usaha, Alfabeta, Bandung, 2013.

Great R, Jones., Oraganizational Theory, New Jersey: USA Prentice-Hall Inc, 2001.

Hadiyanto, Yosi . Aspek Hukum ALWadi'ah Yad Adh-Dhamanah pada perbankan syariah, Article, Fakultas Hukum Universitas Negeri Jember (2013).

Harahap, M. Yahya., Hukum Perseroan Terbatas, Jakarta: Sinar Grafika, 2009, hal. 22.

Nussahid,Fajar., Praktik Kedermawanan Sosial BUMN Analisis terhadap Model Kedermawanan PT Krakatau Stei, PT Pertaminan, PT Terkomunikasi Indonesia, Jurnal Galang, Vo, 1, No. 2, Januari (2006).

Rudito, B., Famiola, M., CSR (Corporate Social 
Responsibility, Bandung: Rekayasa Sains, 2013.

Pakpahan, Rudy Hendra., Eka N. A. M. Sihombing, Tanggung Jawab Negara Dalam Pelaksanaan Jaminan Sosial (Responsibility State In The Implementation of Sosial Security), Jurnal Legislasi Indonesia, Vol. 9 No. 2 - Juli (2012).

Sihombing, Eka N.A.M., Eksistensi Paralegal dalam Pemberian Bantuan Hukum bagi Masyarakat Miskin (The Existence of Paralegals in Providing Legal Aid to the Poor), Jurnal Ilmiah Penegakan Hukum, Vol. 6, No. 1, June (2019).

Solihin, Ismail., Corporate Social Responsibility From Charity to Sustainability, Jakarta: PT. Riau Andalan Pulp and Paper, 2008.

Suharto, Edi., Pekerjaan Sosial di Dunia Industri, Memperkuat CSR, Bandung: CV. Alfabeta, 2009.

Sule, E.T., Kurniawan Saefullah, Pengantar Manajemen, Jakarta: Kencana, 2010.

Suparnyo, Corporate Social Responsibility: Teori dan Praktik, Semarang: Badan Penerbit Universitas Diponegoro, 2010.

Sutamo, Serba-serbi Managemen Bisnis, Yogyakarta: Graha Ilmu, 2012.

Untung, Hendrik Budi., Corporate Social Responsibility (CSR), Jakarta: Sinar Grafika, 2008.
Untung, Hendrik Budi., CSR Dalam Dunia Bisnis, Yogyakarta: ANDI, 2014.

Zaim, S., Abidin, H., Menjadi Bangsa Pemurah: Wacana dan Praktek Kedermawanan Sosial di Indonesia, Jakarta: Piramida, 2004.

1945 Constitution of the Republic of Indonesia.

Law Number 19 of 2003 concerning State-Owned Enterprises.

Law Number 25 of 2007 concerning Investment.

Law Number 40 of 2007 concerning Limited Liability Companies.

Law Number 32 of 2009 concerning Environmental Protection and Management.

Government Regulation Number 47 of 2012 concerning Corporate Social and Environmental Responsibility.

Regulation of the Minister of BUMN Number: Per-05 / MBU / 2007 regarding Community Development Program.

Constitutional Court Decision Number 53 / PUU-VI / 2008, Case on Application for Judgment of Law Number 40 of 2007 concerning Limited Liability Companies, against the 1945 Constitution. April 15, 2009. " 